\title{
Pendidikan Dan Kaitannya Dengan Pertumbuhan Ekonomi Di Provinsi Jambi
}

\author{
oleh: \\ *) Dr. M. Syurya Hidayat, S.E., M.E. \\ **) Dosen Program Magister Ilmu Ekonomi Universitas Jambi)
}

\begin{abstract}
Abstrak
Tujuan dari penelitian yang dilakukan adalah untuk menganalisis kaitan pendidikan dengan pertumbuhan ekonomi. Sehingga pada akhirnya dapat dirumuskan kebijakan dan program peningkatan pendidikan dalam mendukung pertumbuhan ekonomi di Provinsi Jambi. Metode Analisis yang digunakan adalah metode deskriptif kuantitatif beserta metode crosssectional. Hasil analisis menunjukan kaitan antara keluaran pendidikan menengah atas dan kejuruan, dengan pertumbuhan ekonomi belum terlihat secara maksimal. Terdapat kesenjangan antara keluaran pendidikan yang ditawarkan dengan keahlian yang diminta oleh sektor yang menjadi unggulan daerah sehingga menimbulkan pengangguran terdidik. Hal ini juga terjadi pada keluaran pendidikan tinggi.
\end{abstract}

Katakunci: Pendidikan, Pengangguran, Pertumbuhan Ekonomi

\section{PENDAHULUAN}

\section{Latar Belakang}

Komitmen Pemerintah Provinsi Jambi membangun pendidikan patut dihargai.Hal initerlihat dari alokasi dana pendidikan dari APBD Provinsi Jambi yang berupayamemenuhiamanat konstitusi yaitu $20 \%$ dari total anggaran. Namun dalam pelaksanaannya belum optimal menghasilkan keluaran tenaga terdidik yang profesional dan sesuai dengan kebutuhan pasar. Akibatnya tingkat pengangguran terbuka untuk tenaga terdidik masih perlu diperhatikan dengan bijak. Tahun 2012 tercatat 6,80\% lulusan SMA/SMK kategori pengangguran terbuka dan 4,23\% lulusanperguruan tinggi juga masuk pengangguran terbuka di Provinsi Jambi.

Dari sisi ekonomi,pertumbuhanekonomiProvinsi Jambi patut dibanggakan karena tumbuh mencapai $7,4 \%$ pada tahun 2012. Pertumbuhan tersebut diatas rata-rata nasional dengandidukung oleh pertumbuhan yang tinggi padasektor bangunan sebesar 16,1\%. Kemudian diikuti oleh sektor perdagangan, hotel \& restoran sebesar 9,98\% dan sektor industri pengolahan sebesar $7,90 \%$.

Bila dicermati, pendidikan di satu sisi dan pertumbuhan disisi lain maka akan terlihat ada kaitan satu sama lain. Hal ini disebabkan pendidikan adalah produsen tenaga kerja terdidik 
sedangkan sektor lapangan kerja usaha merupakan konsumen dari tenaga kerja terdidik. Analisis permintaan dan penawaran tenaga kerja terdidik tersebut memberi makna atas terjadinya ekses permintaan dan tenaga kerja terdidik yang berakibat munculnya pengangguran terdidik dari alumni SMA/SMK dan perguruan tinggi.

Menganalisis lebih lanjut maka kajian yang lebih mengarah kepada analisis pendidikan dan kaitannya dengan pertumbuhan ekonomi patut dilakukan. Dari analisis tersebut diharapkan agar dapat diperoleh rumusan kebijkan dan program untuk meningkatkan kualitas dan kuantitas pendidikan yang berorientasi pada pertumbuhan ekonomi khususnya di Provinsi Jambi.

\section{Tujuan dan Manfaat}

Analisis pendidikan dan kaitannya dengan pertumbuhan ekonomi di Provinsi Jambi memiliki tujuan yang strategis. Adapun tujuan tersebut adalah:

a. Menganalisis dana dan keluaran pendidikan daerah

b. Menganalisis pertumbuhan ekonomi daerah

c. Menganalisis kaitan pendidikan dengan pertumbuhan ekonomi

d. Merumuskan kebijakan dan program peningkatan pendidikan dalam mendukung pertumbuhan ekonomi

Analis pendidikan dan kaitannya dengan pertumbuhan ekonomi diharapkan memberi nilai guna yang berarti bagi penumbuhkembangan pendidikan yang berorientasi pasar dan mendukung pertumbuhan ekonomi. Oleh karena itu diharapkan hasil analisis tersebut dapat memberi manfaat sebagai berikut:

a. Masukan dalam penentuan besaran dan penggunaan anggaran pendidikan di Provinsi Jambi.

b. Entry point bagi pengembangan pendidikan dalam memanfaatkan peluang dan kesempatan atas pertumbuhan ekonomi Provinsi Jambi yang kategori tinggi di tingkat nasional.

c. Masukan bagi kebijakan dan program penumbuhkembangan pendidikan dalam mendukung pertumbuhan ekonomi Provinsi jambi. 


\section{Metode dan Teknik Analisis}

Metode Analisis yang digunakan adalah metode analisis deskriptif kuantitatif yang digunakan untuk menganalisis dana dan keluaran pendidikan daerah beserta pertumbuhan ekonomi daerah. Sedangkan metode cross-sectional digunakan untuk menganalisis kaitan pendidikan dengan pertumbuhan ekonomi daerah.

Dalam analisa tersebut dilaksanakan pula kajian bersama antara pakar pendidikan dengan pakar ekonomi beserta birokrat pendidikan di Provinsi Jambi guna merumuskan kebijakan dan program peningkatan pendidikan yang mendukung pertumbuhan ekonomi.

\section{LANDASAN KONSEPSIONAL}

\section{Konsepsi Investasi Pendidikan}

Cohn (1979) mengartikan investasi sebagai, "upaya untuk meningkatkan nilai tambah barang ataupun jasa di kemudian hari dengan mengorbankan nilai konsumsi sekarang. Investasi tidak hanya menyangkut dengan uang sebagai modal utama untuk menghasilkan keuntungan di masa depan, tetapi juga mencakup kualitas manusia yang berupa pengetahuan, keterampilan dan kecakapan yang dimiliki seseorang. Makna investasi ini memiliki arti yang relevan dengan pendidikan, karena dengan adanya pendidikan, pengetahuan, keterampilan dan kecakapan serta sikap seseorang akan semakin positif dan bertambah. Siapa saja yang berinvestasi melalui pendidikan akan merasakan atau memetik manfaatnya dikemudian hari atau di masa depan.

Investasi pendidikan memberikan nilai balik (rate of return) yang lebih tinggi dari pada investasi fisik di bidang lain. Nilai balik pendidikan adalah perbandingan antara total biaya yang dikeluarkan untuk membiayai pendidikan dengan total pendapatan yang akan diperoleh setelah seseorang lulus dan memasuki dunia kerja. Di negara-negara sedang berkembang umumnya menunjukkan nilai balik terhadap investasi pendidikan relatif lebih tinggi dari pada investasi modal fisik yaitu $20 \%$ dibanding $15 \%$. Sementara itu di negaranegara maju nilai balik investasi pendidikan lebih rendah dibanding investasi modal fisik yaitu $9 \%$ dibanding $13 \%$. Keadaan ini dapat dijelaskan bahwa dengan jumlah tenaga kerja terdidik yang terampil dan ahli di negara berkembang relatif lebih terbatas jumlahnya dibandingkan dengan kebutuhan sehingga tingkat upah lebih tinggi dan akan menyebabkan nilai balik terhadap pendidikan juga tinggi (Ace Suryadi, Pendidikan, Investasi SDM dan Pembangunan: Isu, Teori dan Aplikasi. Balai Pustaka: Jakarta, 1999, h.247). 


\section{Konsepsi Ekonomi Pendidikan}

Istilah ekonomi dan pendidikan masing masing memiliki pengertian yang berbeda cukup tajam, keduanya merupakan disiplin ilmu pengetahuan. Ekonomi merupakan usaha memanfaatkan segala sumber daya untuk memproduksi komoditas tertentu sedangkan pendidikan sebagai upaya untuk mencerdaskan manusia melalui pengembangan pengetahuan, sikap dan keterampilan supaya berdaya.

Alasan kebutuhan dalam memahami ekonomi pendidikan dikarenakan, bahwa proses pengembangan sumber-daya manusia memerlukan alokasi biaya yang sangat besar yang harus dikelola secara rasional atas pemakaiannya. Kemudian dipertanggungjawabkan. Menurut Elchanan Cohan (2000:18) ekonomi pendidikan didefinisikan sebagai suatu studi tentang bagaimana manusia baik secara perorangan maupun secara kelompok masyarakatnya membuat keputusan dalam mendayagunakan sumber-sumber daya yang terbatas agar dapat menghasilkan berbagai bentuk pendidikan dan latihan, pengembangan ilmu pengetahuan dan keterampilan, pendapat sikap dan nilainilai, khususnya melalui pendidikan formal serta bagaimana mendiskusikannya secara merata (equal) dan adil (equality) diantara berbagai kelompok masyarakat.

Ekonomi pendidikan adalah aktivitas pemenuhan tuntutan permintaan kebutuhan manusia terdidik melalui belajar yang harus dibiayai. Penyelenggarannya dilakukan oleh pemerintah, kelompok masyarakat maupun perorangan. Pendidikan yang diselenggarakan oleh pemerintah disebut pendidikan negeri, yang diselenggarakan oleh kelompok masyarakat dinamakan Pendidikan Swasta.

Teori manusia sebagai modal atau teori Human Capital lebih populer setelah Teodore Schultz, mamperoleh Nobel ekonomi di tahun 1979. Awalnya teori ini dikembangkan oleh Adam Smith. Di Harvard University, teori ini dikembangkan oleh Talcot Parson. Menurutnya, pendidikan yang mengangkat derajat manusia sebab berfungsi sebagai social hange, yang dapat mengangkat manusia kepada derajat perubahan hidup yang lebih baik. Pendidikan berfungsi dinamis, yang memungkinkan manusia melakukan akulturasi budaya sehingga bisa selektif menerima budaya baru yang lebih baik.

Usaha mengangkat masyarakat miskin menjadi sejahtera menurut teori Human Capital tidak tergantung pada uang, lahan, teknologi ataupun kelengkapan industri, melainkan pada pengetahuan yang dimilikinya sebagai modal utama. Manusia menjadi aset utama dalam kegiatan ekonomi, melebihi yang lainnya. Schultz menyebutnya sebagai aspek ekonomi kualitatif. Kecerdasan dan ketrampilan hasil pendidikan inilah yang 
kemudian disumbangkan menjadi karya nyata yang memajukan perekonomian. Teori ini berkonsentrasi pada manusia sebagai faktor produksi yang dominan dalam mengaktifkan peralatan, barang, sumber-daya maupun teknologi sebab semuanya pasif bila tidak digerakkan manusia.

\section{Konsepsi Pendidikan \& Lapangan Kerja}

Diasumsikan bahwa untuk Indonesia, laju pertumbuhan angkatan kerja usia 17-25 tahun akan terus meningkat diatas 10.000 .000 orang pertahun (data 2010), namun pertumuhan lapangan kerja tidak sebanding dengan jumlah usia pencari kerja. Secara keseluruhan terdapat banyak kekurangan penciptaan lapangan kerja, terutama dikalangan terdidik mengakibatkan terjadinya unemployment educated population. Selain tidak ada koordinasi dan sinkronisasi antar departemen dalam penyediaan lapangan kerja bagi lulusan tenaga terdidik, juga karena mereka ditambah dengan migrasi dari desa ke kota, berhubung pendidikan di perkotaan relatif maju dan disitu pula lapangan kerja dipersaingkan diantara mereka.

Akibat tidak adanya korespondensi antara para perencana ekonomi dan perencana pendidikan, akan terjadi kesenjangan diantara dua belah pihak. Pendidikan maupun ekonomi berjalan masing-masing tanpa saling menguntungkan dan melengkapi. Semestinya pendidikan mempersiapkan tenaga cakap yang dibutuhkan ekonomi, dan ekonomi berkembang dikendalikan oleh tenaga cakap hasil pendidikan. Koordinasi antara kedua sektor ini akan menjadikan negara maju dan berkembang secara sinergi.

Unemployment educated population atau populasi pengangguran terdidik sering terjadi akibat tidak adanya kebijaksanaan untuk mensinkronisasikan perencanaan, masingmasing berjalan sendiri-sendiri. Oleh karena itu, implikasinya perlu ada kebijaksanaan yang mengikat supaya kedua masalah ini terjembatani dan ada koordinasi secara terpadu. Pendidikan mempersiapkan program-program yang menghasilkan tenaga kerja sebagaimana dipersyaratkan dunia kerja, ekonomi dan pembangunan memanfaatkan sumber-daya manusia yang cakap (profesional) supaya laju pertumbuhan ekonomi berjalan kokoh. Disamping itu, pendidikan pun menyelenggarakan program-program unggulannya.

\section{Konsepsi Hubungan Pendidikan dan Pertumbuhan Ekonomi}

Pendidikan dan pertumbuhan ekonomi tidak terlepas dari masalah pembangunan. Konsep pebangunan dalam bidang social ekonomi sangat beragam tergantung dari 
penggunaannya. Ahli-ahli ekonomi mengembangkan teori pembangunan yang didasari kepada kapasitas produksi tenaga manusia di dalam proses pembangunan yang kemudian dikenal dengan istilah invesment inhuman Capital. Teori modal manusia ( Teori Human Capital) yang berkembang dewasa ini menjelaskan proses pendidikan yang memiliki proses positif pada pertumbuhan ekonomi. Teori ini mendominasi literature pembangunan ekonomi dan pendidikan pada pasca perang dunia kedua sampai pada tahun 1970-an.

Sumbangan pendidikan terhadap pertumbuhan ekonomi semakin kuat setelah memperhitungkan efek interaksi antara pendidikan dengan bentuk investasi fisik lainnya. Pendekatan di dalam analisis hubungan antara pendidikan dan pertumbuhan ekonomi menggunakan beberapa model, baik yang langsung maupun tidak langsung menghubungkan indicator pendidikan dan indicator ekonomi, seerti model fungsi produksi.

Hal inilah yang menyebabkan teori Human Capital percaya bahwa investasi dalam pendidikan sebagai investasi dalam meningkatkan produktivitas masyarakat. Asumsi dasar yang melandasi keharusan adanya hubungan pendidikan dengan penyiapan tenaga kerja adalah bahwa pendidikan diselenggarakan untuk meningkatkan dan pengetahuan untuk bekerja. Sebagian besar ahli ekonomi sepakat bahwa sumber daya manusia ( Human Resource) dari suatu bangsa sebagai penentu dalam percepatan pembangunan social dan ekonomi bangsa yang bersangkutan.

Modal manusia tersebut tidak hanya menyangkut kuantitas, tetapi yang jauh lebih penting adalah dari segi kualitas. Karena itu, investasi di bidang pendidikan tidak saja berfaedah bagi perorangan, tetapi juga bagi komunitas bisnis dan masyarakat umum. Pencapaian pendidikan pada semua level niscaya akan meningkatkan pendapatan dan produktivitas masyarakat. Pendidikan merupakan jalan menuju kemajuan dan pencapaian kesejahteraan sosial dan ekonomi.

\section{ANALISIS DANA PENDIDIKAN}

\section{Dana APBD Provinsi Jambi}

Pemerintah Provinsi Jambi melalui Dinas Pendidikan Provinsi Jambi telah melakukan berbagai upaya dan program dalam bidang pendidikan guna meningkatkan pemahaman dan motivasi masyarakat terhadap pentingnya pendidikan. Anggaran Belanja Langsung untuk Dinas Pendidikan Provinsi Jambi melalui APBD tahun 2012 dialokasikan sebesar Rp.201.311.101.479,00 dan telah terealisasi sebesar RP.183.173.627.433,00 atau 
sebesar 90,99\%. Adapun anggaran yang tidak terserap pada anggaran Dinas Pendidikan melalui APBD tahun 2012 sebesar Rp.18.137.474.046 atau 9,01\%.

Program Pendidikan Sekolah Menengah diarahkan dalam rangka upaya perluasan akses layanan dan meningkatkan mutu keluaran/lulusan melalui berbagai upaya antara lain pemberian bantuan operasional, penyediaan ruang kelas, peningkatan bakat dan prestas siswa baik umum (SMA) maupun kejuruan (SMK).

Selain pada jenjang pendidikan umum, Dinas Pendidikan Provinsi Jambi juga telah melaksanakan perhatian terhadap fasilitas pendidikan pada Pondok Pesantren antara lain dengan pembangunan 2 ruang kelas baru, pengadaan alat labor IPA 1 paket, pengadaan meubeler Pondok Pesantren 2 ruang, pengadaan komputer 2 unit dengan harapan satuan pendidikan pada jenjang menengah yang tersebar di wilayah Provinsi Jambi dapat melayani kebutuhan masyarakat dalam bidang pendidikan.

Dari upaya-upaya yang sudah dilakukan tersebut berdampak terhdadap target capaian indikator kinerja bidang pendidikan pada RPJMD antara lain Angka Partisipasi Murni pada jenjang PAUD sebesar 64,80\%, jenjang SD 99,90\% , jenjang SMP 98,15\% dan jenjang pendidikan menengah 67,09\%. Selain hal tersebut, untuk menunjang proses belajar mengajar, Dinas Pendidikan Provinsi Jambi juga telah mengadakan dan mendistribusikan Meubeler, Alat Permainan Edikatif (APE) dan beberapa perangkat komputer.

\section{Dana APBN}

Berdasarkan data, alokasi anggaran pendidikan melalui dana APBN selama 8 tahun terakhir cenderung menunjukkan peningkatan yang signifikan setiap tahunnya namun proporsi nya jika dilihat dari sisi APBD Pendidikan Provinsi Jambi bisa dikatakan cukup fluktuatif dimana pada tahun 2005 proporsi APBD Pendidikan Provinsi Jambi terhadap APBN sebesar 46,2\%, pada tahun 2006 turun menjadi 28,1\% namun meningkat kembali pada tahun 2007 sebesar 74,3\% dan kemudian turun pada tahun 2008 menjadi 59,1\% diikuti penurunan pada tahun 2009 sebesar 33,0\%, tahun 2010 21,3\% hingga pada tahun 2011 naik menjadi 95,4\% terus meningkat pada tahun 2012 menjadi 22,8\%.

Bisa dilihat bahwa proporsi terbesar terjadi pada tahun 2012 (228,5\%) dan proporsi terendah pada tahun 2010 (21,3\%). Tingginya proporsi APBD Pendidikan terhadap APBN mencerminkan komitmen Pemerintah Daerah Provinsi Jambi terhadap pembangunan pendidikan yang cukup tinggi, anggaran yang terkonsentrasi dan indikator pelaksanaan 
pendidikan yang transparan. Sebaliknya, rendahnya proporsi APBD Pendidikan Provinsi Jambi terhadap APBN mencerminkan tingginya ketergantungan terhadap pemerintah pusat, program yang tidak fokus dan lemahnya standar pelayanan minimal terhadap pendidikan.

Salah satu faktor tingginya proporsi APBD pendidikan Provinsi Jambi terhadap APBN pada tahun 2012 adalah karena gaji guru sertifikas khusus pegawai negeri sudah diserahkan keapda kabupaten/kota masing-masing oleh Pemerintah Pusat, program pemberian beasiswa S1, S2 dan S3 serta adanya program percepatan pengembangan SMK dengan porsi perbandingan terhadap SMA sebesar $70: 30$. Ketergantungan terhadap pemerintah pusat masih cukup besar dikarenakan Pemerintah Daerah belum mampu untuk membiayai guru, rehabilitasi sekolah, pendidikan khusus/layanan khusus, pembangunan fisik pendidikan dan biaya operasional sekolah.

\section{KELUARAN PENDIDIKAN DAERAH}

\section{Keluaran Pendidikan Menengah Atas dan Kejuruan}

Data memperlihatkan portal Ujian Nasional telah mengurangi kelulusan siswa SMA beserta SMK sehingga capaian kelulusan yang sempurna (100\%) sulit dicapai. Hal tersebut dilihat dari persentase tingkat kelulusan masih dibawah sempurna. Bahkan pada tahun 2010, tingkat kelulusan sempat dibawa 90\%. Dari segi institusi pendidikan, kelulusan siswa SMA dan SMK didominasi oleh sekolah milik pemerintah, khsusunya SMA. Sedangkan untuk SMK masih berimbang antara kelulusan SMK milik Pemerintah dan SMK milik swasta.

Lulusan SMA dan SMK didominasi oleh lulusan SMA Negeri. Ini berarti, akan ada pula potensi tenaga kerja yang didominasi oleh lulusan SMA yang mayoritas jurusan IPS plus Bahasa atau Program Studi Ilmu Sosial. Tidak semua lulusan tersebut melanjutkan pendidikan ke jenjang pendidikan tinggi karena keterbatasan dalam bentuk finansial (dana) maupun keterbatasan yang bersifat akademis sehingga sebagian dari lulusan SMA tersebut akan masuk lapangan kerja dengan kompetensi yang sangat minimal dari yang dibutuhkan oleh lapangan kerja.

\section{Keluaran Pendidikan Tinggi}

Jumlah lulusan atau alumni pendidikan tinggi terus bertambah sejalan dengan bertambahnya jumlah PTN dan PTS di Provinsi Jambi. Jumlah PTN bertambah melalui 
pembukaan kampus-kampus jauh, sedangkan PTS bertambah melalui PTS baru di Kabupaten/Kota di lingkungan Provinsi Jambi. Proporsi alumni PTN dan PTS berbanding 1:2.5, hal ini berarti dominasi alumni pendidikan tinggi oleh alumni PTS lebih banyak dibandingkan PTN.

Dari paparan data terlihat pula ekspansi alumni PTS pada pasar tenaga kerja. Namun cukup disayangkan bahwa kenyataanya mayoritas alumni tersebut berlatar belakang keilmuan non-teknik. Sangat sedikit alumni teknik dari PTN dan PTS dikarenakan program studi jurusan teknik sangat terbatas jumlahnya dan juga minat masyarakat untuk masuk program studi teknik juga sangat minim disebabkan adanya kecenderungan masyarakat saat ini untuk memilih pendidikan tinggi berkategori program studi non-teknik yang gelar kesarjanaannya mudah dan instan untuk diperoleh. Akan tetapi kemudahan tersebut tidak diikuti oleh ketrampilan/kompetensi yang sesuai dan sdibutuhkan oleh lapangan kerja saat ini.

Berdasarkan strata pendidikan, alumni PTN dan PTS didominasi juga alumni dengan tingkatan strata satu (Sarjana). Cukup disayangkan strara nol (Diploma) atau jalur vokasi, alumninya sangat sedikit sekali. Berarti pencari kerja dari alumni pendidikan tinggi di Provinsi Jambi mayoritas bergelar Sarjana tetapi ketrampilan kerja atau kompetensi nya minim dikarenakan berbasis pendidikan jalur akademis.

Alumni strata dua (Magister) kendatipun masih sedikit, tetapi akan terus bertambah sejalan dengan pembukaan pendidikan strata dua (S2) pada PTN dan PTS. Bagi peserta didik yang sudah bekerja dan melanjutkan pendidikan strata dua (S2) amat baik untuk peningkatan kompetensi dan akademis dalam bekerja agar menjadi pekerja yang profesional.

Mengacu kepada alumni pendidikan tinggi berdasarkan strata pendidikan, maka kelembagaan pendidikan tinggi penghasil alumni juga didominasi oleh Universitas dan Sekolah Tinggi. Hal tersebut bisa dilihat dari besarnya lulusan strata 1 (Sarjana) setiap tahunnya yang menjadi mayoritas dari alumni pendidikan tinggi di Provinsi Jambi. Kelembagaan Universitas dan Sekolah Tinggi penghasil alumni bergelar sarjana di Provinsi Jambi cukup beragam. Pendidikan universitas dan sekolah tinggi penghasil tenaga kerja bergelar sarjana perlu distrukturisasi karena yang dibutuhkan oleh pasar tenaga kerja adalah lulusan yang memiliki kompetensi dan kelebihan bersifat teknik ataupun soft-skill personal bukan gelar kesarjanaan yang dianggap hanya memiliki kelebihan pada sisi akademis saja. Oleh karena itu, diperlukan reorientasi dari gelar kesarjanaan menjadi 
lulusan berkompetensi/keahlian yang siap kerja bukan siap di-training kembali untuk menjadi siap pakai.

\section{ANALISIS PEREKONOMIAN}

Peningkatan pertumbuhan ekonomi Provinsi Jambi didukung oleh semua sektor ekonomi dengan pertumbuhan tertinggi pada sektor bangunan yang mencapai $16,16 \%$ diikuti sektor perdagangan hotel dan restoran sebesar 9,98\% industri pengolahan 7,90\% dan sektor keuangan, persewaan dan jasa 7,81\% serta sektor pertanian 7,60\%. Sedangkan sektor ekonomi yang laju pertumbuhan ekonominya terkecil pada sektor pertambangan dan penggalian 2,62\%. Laju pertumbuhan ekonomi tahun 2012 sebesar 8,69\% didukung oleh sumber pertumbuhan utama pada sektor pertanian sebesar 2,24\% diikuti oleh sektor perdagangan hotel dan restoran sebesar $1,76 \%$.

Struktur PDRB menurut penggunaan, pada komponen konsumsi rumah tangga mengalami penurunan dari 59,86\% pada tahun 2011 menjadi 57,74\% pada tahun 2012; pengeluaran konsumsi Pemerintah menurun dari 18,12\% pada tahun 2011 menjadi 17,76\%; begitu juga dengan komponen ekspor dari 55,82\% pada tahun 2011 menjadi 47,48\%. Sedangkan Pembentukan Modal Tetap Bruto mengalami peningkatan dari 16,80\% pada tahun 2011 menjadi $17,81 \%$ di tahun 2012.

Kinerja ekonomi Provinsi Jambi yang cukup baik ini, juga ditunjukkan dengan angka inflasi yang cukup rendah dan stabil. Laju inflasi Provinsi Jambi tahun 2012 berada pada posisi $4,22 \%$ masih dibawah angka proyeksi nasional sebesar 4,5\%. Inflasi yang terjadi selama kurun waktu 2012, rerata pada empat kelompok barang dan jasa yaitu kelompok bahan makanan, kelompok sandang, kelompok kesehatan, dan kelompok transport, komunikasi dan jasa keuangan.

Pertumbuhan ekonomi Provinsi Jambi, juga berimplikasi pada penurunan angka pengangguran dari 4,02\% pada Agustus 2011 menjadi 3,22 \% pada Agustus 2012, dan jumlah penduduk yang memiliki pendapatan dibawah garis kemiskinan juga mengalami penurunan dari 272,67 ribu orang pada tahun 2012.

Geliat ekonomi dan perdagangan Provinsi Jambi yang terus tumbuh dengan baik, dan menjadi daya tarik investor luar, juga ditunjukkan dengan meningkatnya peredaran uang tunai dan transaksi giralisasi. Meningkatnya pertumbuhan ekonomi Jambi telah menarik minat dunia perbankan untuk membuka operasionalisasinya di Jambi yang sampai saat ini 
berdasarkan Jurnal Bank Indonesia tahun 2012 telah terdapat 30 Bank Umum dan 16 BPR dengan 325 kantor bank.

\section{Analisis Perubahan Struktur}

Struktur ekonomi daerah untuk Provinsi Jambi didominasi oleh sektor pertanian berkontribusi terhadap PDRB Provinsi jambi sebesar 29,47\% (tahun 2012). Hal ini berarti, sektor pertanian punya peran besar dalam perekonomian Provinsi Jambi. Daya serap tenaga kerja juga pada sektor pertanian yang terbesar. Sektor perdagangan, Hotel \& Restoran menjadi sektor dominan urutan kedua 18.03\%. Sedangkan sektor pertambangan dan galian merupakan pula sektor dominan urutan ketiga sebesar 13,31\%.

Pada tahun 2012, pertumbuhan per sektor yang terbesar pada sektor pertanian. Kemudian diikuti oleh sektor perdagangan, hotel \& restoran. Sedangkan sektor industri pengolahan menempati urutan ketiga. Ini berarti, sektor yang punya kontribusi terbesar dan laju pertumbuhan sektoral terbesar adalah juga sektor pertanian. Sektor industri pengeolahan diharapkan menjadi sektor yang berperan bagi peningkatan nilai tambah produk pertanian masih perlu menjadi perhatian dan dorongan yang lebih agar percepatan perubahan struktur terjadi dari dominasi pertanian menuju dominasi industri pengolahan.

\section{Analisis Angkatan Kerja dan Pengangguran Daerah}

Ketenagakerjaan Provinsi Jambi mengalami perubahan pada indikator yang signifikan, seperti jumlah angkatan kerja yang meningkat dari 1.527,5 ribu orang pada Februari 2010 menjadi 1.551,0 ribu orang pada bulan Februari 2011. Kemudian angkatan kerja meningkat kembali pada bulan Februari 2013 menjadi 1.582,0 ribu orang. Peningkatan pada angka angkatan kerja di Provinsi ini belum mampu meningkatkan Tingkat Partisipasi Angkatan Kerja (TPAK). TPAK Provinsi Jambi dua tahun terakhir menurun, yaitu dari 69,91 persen pada bulan Februari 2011 menjadi 69,21 persen pada bulan Februari 2012. Kemudian pada bulan Februari 2013 menurun kembali menjadi 69,21 persen.

Data memperlihatkan bahwa jumlah penduduk yang bekerja terus mengalami peningkatan.Tercatat pada Februari 2011 jumlah penduduk yang bekerja sebesar 1.468,7 ribu orang, bertambah 25,7 ribu orang pada Februari 2012 menjadi 1.494,4 ribu orang dan pada Februari 2013 bertambah 41,8 ribu orang menjadi 1.536,2 ribu orang. Penganggur pada Februari 2011 sebesar 58,8 ribu orang, dan berkurang pada Februari 2012 menjadi 56,6 ribu orang. Februari 2013 penganggur turun menjadi 45,9 ribu orang, sehingga dalam 
kurun waktu dua tahun terakhir tersebut jumlah penganggur turun sebesar 21,85 persen atau 12,9 ribu orang.

\section{Analisis Lapangan Kerja dan Status Pekerjaan Daerah}

\section{Lapangan Kerja Daerah}

Bulan Februari 2013 tercatat bahwa sektor pertanian, perkebunan, kehutanan, perburuan dan perikanan masih menjadi lapangan pekerjaan yang paling dominan menyerap tenaga kerja yaitu 832,5 ribu orang (54,19 persen). Kemudian disusul sektor perdagangan, rumah makan dan jasa akomodasi 246,8 ribu orang (16,07 persen) dan sektor jasa kemasyarakatan, sosial dan perorangan 242,0 ribu orang (15,75 persen).

Penurunan jumlah pekerja pada periode Februari 2012-Februari 2013 terjadi pada sektor pertanian, perkebunan, kehutanan, perburuan dan perikanan, kemudian sektor listrik, gas dan air minum, dan sektor lembaga keuangan, real estate, usaha persewaan dan jasa perusahaan. Meskipun sektor pertanian, perkebunan, kehutanan, perburuan dan perikanan masih menjadi sektor utama penyerap tenaga kerja terbesar, tetapi dari tahun ke tahun jumlah tenaga kerja di sektor ini terus mengalami penurunan.

\section{Status Pekerjaan Daerah}

Berdasarkan status pekerjaan, pekerja formal hanya terdiri darikategori berusaha dengan dibantu buruh tetap dan kategori buruh/karyawan. Dilihat dari status pekerjaan berdasarkan klasifikasi formal dan informal, maka pada Februari 2013 terdapat sekitar 39,95 persen tenaga kerja bekerja pada kegiatan formal dan 60,05 persen bekerja pada kegiatan informal.

Dari 1.536,2 ribu orang yang bekerja pada Februari 2013, terdapat 543,0 ribu orang $(35,34$ persen) penduduk yang bekerja sebagai buruh/karyawan, 288,6 ribu orang $(18,79$ persen) merupakan pekerja keluarga/ pekerja yang tidak dibayar. Sedangkan sebanyak 278,2 ribu orang, (18,11 persen) berusaha sendiri dan status dibantu buruh tidak tetap/tidak dibayar sebanyak 230,9 ribu orang (15,03 persen).

\section{Analisis Pekerjaan dan Pendidikan}

Data bulan Februari 2013 menunjukkan bahwa jumlah penduduk bekerja dengan jenjang pendidikan tertinggi yang ditamatkan SD ke bawah sebesar 715,9 ribu orang 
menurun jika dibandingkan kondisi Februari 2012 sebesar 752,8 ribu orang. Kenaikan jumlah penduduk yang bekerja juga terjadi pada semua jenjang pendidikan.

Berdasarkan data dapat diamati bahwa pekerja di Provinsi Jambi masih didominasi oleh pekerja yang berpendidikan rendah. Dari 1.536,2 pekerja di Provinsi Jambi pada Februari 2013, didapati 46,60 persen adalah pekerja dengan jenjang pendidikan SD ke bawah. Kemudian sebanyak 296,0 ribu orang (19,27 persen) berpendidikan sekolah menengah pertama dan 363,7 ribu orang $(23,68$ persen) berpendidikan sekolah menengah umum dan kejuruan. Untuk pekerja dengan ijasah tertinggi diploma I/II/III dan univeritas sebesar 160,6 ribu orang $(10,45$ persen $)$.

\section{Analisis Pengangguran Daerah}

Pengangguran pada Februari 2013 didapati 45,9 ribu orang atau 2,90 persen dari total angkatan kerja.Kondisi tersebut menurun dibandingkan keadaan Februari 2011 maupun Februari 2012, dimana tingkat pengangguran terbuka (TPT) pada Februari 2012 sebesar 3,65 persen dan sebesar 3,85 persen pada Februari 2011.

Menganalisis tingkat pengangguran terbuka berdasarkan pendidikan tertinggi yang ditamatkan, Tingkat Pengangguran Tertinggi berada pada pendidikan diploma I/II/III dan universitas yakni sebesar 7,58 persen. Sementara pengangguran terbuka terendah pada pendidikan SD ke bawah sebesar 2,03 persen, dan pada jenjang pendidikan SMP sebesar 2,10 persen. Tingginya pengangguran terbuka pada pendidikan tinggi sangat terkait dengan lapangan pekerjaan yang tersedia. Lapangan pekerjaan yang banyak tersedia adalah sektor pertanian dengan kegiatan informal dan perkebunan, sementara pencari kerja tamatan pendidikan tinggi lebih cendrung pada kegiatan formal.

\section{ANALISIS KAITAN PENDIDIKAN DENGAN PERTUMBUHAN EKONOMI}

Menganalisis kaitan pendidikan menengah atas dan kejuruan dengan pertumbuhan ekonomi membutuhkan ketetapan tentang sektor yang diunggulkan dalam memacu pertumbuhan ekonomi. Sektor unggulan tersebut membutuhkan tenaga kerja yang berasal dari kategori pendidikan menengah atas dan kejuruan untuk menjadi pekerja pada sektor itu pula.

Oleh karena itu, penetapan sektor unggulan yang mendorong pertumbuhan ekonomi pada Kabupaten/Kota dalam Provinsi Jambi sangat diperlukan. Disamping itu, bidang keahlian yang ditawarkan oleh alumni pendidikan menengah atas dan kejuruan juga 
menentukan kesesuaian antara bidang keahlian yang ditawarkan dengan bidang keahlian sektor unggulan. Bila terjagi ekses antara keahlian yang ditawarkan denagn yang diminta, maka akan dimungkinkan terjadinya pengangguran. Maka diperlukan analisis kaitan antara keluaran pendidikan menengah atas dengan pertumbuhan ekonomi yang berbasis pada sektor unggulan.

Terdapat 7 Kabupaten yang percepatan pertumbuhan ekonominya berbasis pada sektor pertaninan, perkebunan, kehutanan, peternakan dan perikanan. Sedangkan untuk Kota Jambi dan Kota Sungai Penuh berbasis pada sektor perdagangan, hotel dan restoran. Khusus untuk Kabupaten Tanjung Jabung Barat, berbais pada sektor industri pengolahan. Sedangkan untuk Kabupaten Tanjung Jabung Timur berbasis pada sektor pertambangan.

Secara keseluruhan, sektor basis perekonomian di Provinsi Jambi adalah sektor pertanian, perkebunan, kehutanan, peternakan dan perikanan. Namun pada sisi lain, komposisi perbandingan antara SMA dan SMK adalah 61,30\% : 38.7\%. Sebaran untuk Kabupaten/Kota didominasi oleh SMA. Ini berarti, SMK hanya merupakan jenjang pendidikan menengah minoritas dan kurang diminati oleh pihak swasta karena dimiliki oleh Pemerintah (SMK Negeri).

Berkaitan dengan keluaran pendidikan menengah atas dan kejuruan dengan sektor yang menjadi unggulan pada pertumbuhan ekonomi, maka belum terlihat dukungan maksimal SMK terhadap sektor tersebut karena populasi SMK yang hanya berjumlah 138 sekolah. Sedangkan populasi SMP jauh lebih banyak, yaitu 219 sekolah.

Keluaran SMA lebih disiapkan untuk langsung memasuki lapangan kerja, sedangkan SMK diharapkan memang siap dijadikan tenaga kerja. Ini berarti, diperlukan reorientasi komposisi SMA dan SMK agar mendukung sektor yang menjadi unggulan dalam pertumbuhan ekonomi. Minimal dibutuhkan 70\% SMK dan 30\% SMA agar kebutuhan tenaga kerja yang siap kerja dapat terpenuhi.

Disamping itu, SMK yang ditumbuhkembangkan juga harus berbasis pada sektor yang menjadi unggulan pada pertumbuhan ekonomi daerah. Maka diperlukan pendirian SMK Pertanian pada 7 Kabupaten yang memiliki sektor basis pertanian sebagai sektor unggulan. Khusus untuk Kota Jambi dan Kota Sungai Penuh dibutuhkan SMK Kepariwisataan, disamping SMK Bisnis, Niaga. Sedangkan Kabupaten Tanjung Jabung Barat membutuhkan SMK Industri, dan Kabupaten Tnajung Jabung Timur membutuhkan SMK Pertambangan.

Analisis kaitan diatas membutuhkan pemikiran untuk membangun kembali pendidikan menengah kejuruan yang berbasis pada bidang pertanian, seperti yang perbah 
ditumbuh kembangkan sewaktu orde baru dimana Sekolah Pertanian Menengah Atas (SPMA) dan Sekolah Pertanian Pembangunan (SPP) menjadi unggulan untuk mencetak kader-kader penyuluh \& motivator pertanian di wilayah pedesaan. Oleh karena itu, pengembangan pendidikan kejuruan untuk pertanian perlu mengkaji keberhasilan SPMA dan SPP tersebut untuk kemudian diterapkan ke dalam Sekolah Menengah Kejuruan Pertanian

\section{ANALISIS KAITAN PENDIDIKAN TINGGI DENGAN PERTUMBUHAN EKONOMI}

Dari data bidang ilmu/ program studi yang telah ditumbuhkembangkan terlihat kesenjangan antara keahlian yang ditawarkan pendidikan tinggi dengan keahlian yang diminta oleh sektor yang mendorong pertumbuhan ekonomi. Sektor unggulan untuk pertumbuhan ekonomi di Kabupaten/Kota di Provinsi Jambi didominasi oleh sektor pertaninan, perkebunan, peternakan, kehutanan dan perikanan. Namun untuk Kota Jambi dan Kota Sungai Penuh, sektor yang menjadi unggulan adalah sektor perdagangan, hotel dan restoran. Sedangkan pada Kabupaten Tanjung Jabung Barat sektor unggulannya adalah Industri Pengolahan dan Kabupaten Tanjung Jabung Timur sektor unggulannya adalah sektor pertambangan dan penggalian.

Pada sisi lain, pendidikan tinggi di Provinsi Jambi menawarkan beberapa bidang pendidikan untuk keluaran pendidikan. Keluaran pendidikan terbanyak adalah untuk bidang sosial, terbanyak kedua adalah bidang kesehatan dan terbanyak ketiga adalah bidang agama. Bila dihubungkan dengan kebutuhan pada sektor unggulan pendukung laju pertumbuhan ekonomi tiap daerah Kabupaten/Kota dalam Provinsi Jambi, terdapat kesenjangan antara tenaga kerja berkeahlian yang diminta (demand) dengan yang ditawarkan (supply) oleh pendidikan tinggi di lingkungan Provinsi Jambi. Akibatnya, telah dan akan berdampak pada angka pengangguran berpendidikan tinggi yang meningkat setiap tahunnya karena kebutuhan keahlian pendidikan tinggi untuk sektor unggulan penunjang pertumbuhan ekonomi tidak terpenuhi. Ini berarti diperlukan kebijakan restrukturisasi pendidikan tinggi yang berorientasi pada permintaan pasar atau kebutuhan sektor unggulan untuk mendorong pertumbuhan ekonomi, khususnya di Provinsi Jambi.

Restrukturisasi pendidikan tinggi diarahkan kepada vocational education (politeknik) agar siap bekerja untuk sektor yang memacu ekonomi tumbuh lebih baik lagi. Untuk itu, direkomendasikan pendidikan politeknik baru dengan kekhususan atau spesialisasi di bidang pertanian, industri dan pertambangan. 
Pendidikan pada bidang politeknik tersebut juga telah diamanatkan dalam Undangundang Pendidikan Tinggi dimana setiap Provinsi minimal memiliki 1 politeknik Negeri. Ini berarti Pemerintah Provinsi Jambi perlu meresponi amanat tersebut dengan pendirian Politeknik Negeri Jambi dengan bidang keahlian pertanian, industri dan pertambangan.

Diharapkan restrukturisasi pendidikan tinggi berorientasi pada politeknik industri dan tambang akan dapat menekan angka pengangguran alumni atau lulusan pendidikan tinggi dan pemenuhan kebutuhan tenaga kerja untuk sektor unggulan dalam rangka peningkatan laju pertumbuhan ekonomi oleh angkatan kerja dari Provinsi Jambi.

\section{Kesimpulan dan Saran}

\section{Kesimpulan}

Beranjak dari paparan analisis pendidikan dan kaitannya dengan pertumbuhan ekonomi, maka dapat dirumuskan butir kesimpulan sebagai berikut:

1. Keluaran pendidikan menengah atas dan kejuruan masih dodominasi oleh lulusan SMA. Hal ini terjadi karena populai pendidikan menengah atas mendominasi sebesar $61,30 \%$ dan sisanya 38,7 \% merupakan keluaran SMK. Sedangkan untuk pendidikan tinggi, didominasi oleh sekolah tinggi yang menumbuhkembangkan bidang keahlian sosial, kesehatan dan keagamaan. Pengelolaan pendidikan tersebut didominas pula oleh Pemerintah sehingga ketergantungan pada dana APBN dan APBD Provinsi dan Kabuapten/Kota sangat besar kendatipun target alokas dana telah melebihi (diatas 20\%) amanat konstitusi.

2. Capaian pertumbuhan ekonomi Provinsi Jambi melebihi dari pertumbuhan ekonomi nasional. Berarti ekonomi Provinsi Jambi tumbuh dan berkembang lebih cepat yang didukung oleh sektor unggulannya, yaitu Pertanian, Peternakan, Perkebunan, Kehutanan dan Perikanan. Struktur perekonomian Provinsi Jambi masih didominasi oleh sektor pertanian, sehingga tenaga kerja yang dibutuhkan harus berbasis pada keahlian di bidang pertanian dalam arti yang luas.

3. Kaitan antara keluaran pendidikan menengah atas dan kejuruan, dengan pertumbuhan ekonomi khususnya sektor yang dominan dalam pertumbuhan ekonomi, belum terlihat secara maksimal. Terdapat kesenjangan antara keluaran pendidikan yang ditawarkan dengan keahlian yang diminta oleh sektor yang menjadi unggulan daerah sehingga menimbulkan pengangguran terdidik. Hal ini juga terjadi pada keluaran pendidikan 
tinggi dimana mayoritas alumni pendidikan tinggi di Provinsi Jambi memiliki keahlian di bidang sosial, kesehatan dan agama. Sedangkan keahlian yang dibutuhkan oleh sektor unggulan yang memacu pertumbuhan ekonomi adalah teknik, pertaninan, industri dan pertambangan.

4. Dilihat dari sisi kesenjangan antara keahlian yang ditawarkan oleh keluaran pendidikan dengan keahlian yang diminta oleh sektor unggulan, maka terdapat kesenjangan yang menimbulkan tingginya tingkat pengangguran terbuka yang berpendidikan. Untuk mengatasinya diperlukan kegiatan dan program yang berorientasi kepada pendidikan menengah dan kejuruan sehingga komposisi pendidikan kejuruan mencapai $70 \%$ dan pendidikan menengah atas 30\%. Sedangkan pendidikan tinggi harus didominasi oleh pendidikan teknik dalam bentuk politeknik sehingga diperlukan pendirian Politeknik Negeri Jambi sesuai dengan permintaan sektor unggulan yang menjadi pendorong pertumbuhan ekonomi.

\section{Saran}

Mengacu kepada kesimpulan maka diperlukan rekomendasi tindak lanjut sebagai berikut:

a. Pemerintah Provinsi bersama Pemerintah Kabupaten/Kota perlu merestrukturisasi pendidikan menengah atas dan kejuruan dengan merubah komposisi $70 \%$ untuk SMK dan 30\% untuk SMA. Bidang keahlian yang ditumbuh kembangkan pada SMK adalah pertanian, industri, pertambangan dan pariwisata.

b. Pemerintah Provinsi Jambi perlu segera mendirikan Politeknik Negeri Jambi guna memenuhi tuntutan kebutuhan ketenagakerjaan sesuai dengan sektor yang jadi unggulan dalam pertumbuhan ekonomi dan amanat undang-undang pendidikan tinggi yang mengharuskan adanya Politeknik Negeri dengan bidang keahlian yang didominasi oleh teknik pertanian, industri, pertambangan dan pariwisata.

c. Untuk menumbuh kembangkan SMK dan Politeknik yang berbasis pada bidang pertanian, industri, pertambangan dan pariwisata maka perlu dbangun kemitraan antara lembaga penyedia pendidikan, baik pemerintah maupun swasta dengan pelaku usaha pada sektor yang menjadi unggulan dalam pertumbuhan ekonomi. Dari kemitraan tersebut dapat digunakan untuk membangunn infrastruktur pendidikan dan peningkatan kualitas proses belajar mengajar dan jaminan kerja bagi lulusan. 
d. Pemerintah Provinsi Jambi perlu meningkatkan alokasi dana Pendidikan khususnya untuk membiayai pembangunan infrastruktur pendidikan Sekolah Menengah Kejuruan (SMK) dan Politeknik yang berbasis pada kebutuhan pasar kerja. Oleh karena itu, SMK dan Politeknik yang kompeten harus dilengkapi infrastruktur pendidikan yang lengkap dan juga berdayasaing sehingga mampu menghasilkan tenaga kerja yang memiliki skill bekerja sesuai dengan kebutuhan pasar tenaga kerja.

\section{DAFTAR PUSTAKA}

. (2010), Dinas Pendapatan Daerah, Kota Jambi.

. (2007), Undang - undang No 34 tahun 2000

. (2007-2011), Jambi Dalam Angka, BPS Kota Jambi

. (2007), Panduan Pariwisata Jambi, Dinas Pariwisata Seni dan Budaya Kota Jambi

Davas ( 2009 ), Keuangan Pemerintah daerah Indonesia, UI - Press, Jakarta

Tunggal, Hadi S, ( 2000 ), Tanya Jawab Pajak Penghasilan, Harvarindo, Jakarta

Tjiptoherjanto, ( 2008 ), Keuangan Daerah dan Retribusi daerah, Rajawali, Jakarta

Suparmoko ( 2002 ), Keuangan Negara Dalam Teori dan Praktek, BPFE, Jakarta

Yoke Putra ( 2005 ), Analisis Potensi Penerimaan Retribusi Terminal di Kota Jambi, STIE Muhammadiyah Jambi.

The , Gie, Liang ( 2004 ), Analisis Ekonomi Politik Indonesia, PT Gramedia Pustaka Utama, dan STIE IBII, Jakarta. 